\title{
The Retromolar Space and Wisdom Teeth in Humans: Reasons for Surgical Tooth Extraction
}

\author{
Abed El Kaseh ${ }^{1} \quad$ Maher Al Shayeb ${ }^{1} \quad$ Syed Kuduruthullah ${ }^{2} \quad$ Nadeem Gulrez ${ }^{2}$ \\ ${ }^{1}$ Surgical Science Department, Ajman University, Ajman, \\ United Arab Emirates \\ ${ }^{2}$ Basic Medical Science Department, Ajman University, Ajman, \\ United Arab Emirates

\begin{abstract}
Address for correspondence Dr. Maher Al Shayeb, DDS, Msc (Oral and Maxillofacial Surgery), Surgical Science Department, Ajman University, Ajman, United Arab Emirates
\end{abstract} \\ (e-mail: m.alshayeb@ajman.ac.ae).
}

Eur J Dent:2021;5:117-121

\begin{abstract}
Keywords

- impaction

- lower jaw

- retromolar space

- third molar

- wisdom teeth
\end{abstract}

Objective This article explores the problem of developing pathologies in the retromolar region. Findings can serve a framework for disease prevention and for the improvement of the quality of life of patients. The present study aims to justify the possibility of utilizing morphometric methods to foresee problems in the eruption of third molars.

Materials and Methods A comprehensive morphometric study of the lower jaw and facial skeleton involves 100 skulls of Homo sapiens to identify the anatomical causes of problems with wisdom teeth eruption. All said skulls are divided in two groups: I: skulls with intact dentition; II: skulls with impacted third molars.

Results This work allows detecting abnormalities in the eruption of the third molar with high probability of success. The abnormalities in point are considered not only those associated with the generally accepted parameters but also those that occur in the leptoprosopic face cases.

Conclusions Face type and the structural features of the facial skeleton play a significant role in the abnormal eruption of the lower third molar.

\section{Introduction}

The third molar retention and removal are one of the constantly relevant issues in modern dentistry. ${ }^{1}$ Besides these, the range of dentists' interests constitutes the eruptive characteristics of a potentially erupting molar, the impaction potential, and the consequences of partial eruption and teeth displacement. 2,3

According to an extensive 10 -year study on 8,000 patients in the United Kingdom, a fifth of all third molars were nonsymptomatic, while one-third molar was removed to prevent impaction. The remaining third molars were removed due to complaints or poor condition. ${ }^{4}$ The improper positioning of teeth leads to impaction or semi-impaction, especially in the lower jaw. Hence, the removal of third molars should be not so much a preventive measure as a therapeutic decision. Among tooth complications were follicular cysts, inflammatory processes of different severity, occlusal disturbances, pathologies in the hard tissue surrounding the neighboring teeth, and even neoplasms.

When erupting, third molars contribute to dental crowding in the lower jaw. Indications for the removal of impacted third molars are: (1) inflammation; (2) inability to use third molars to support the prosthetic; (3) preventive treatment to normalize second molars and tissues surrounding the third molars.

According to several reports, every fifth person has anatomically and functionally normal wisdom teeth. ${ }^{5}$ The remaining $80 \%$ removed their third molars prophylactically or by necessity. ${ }^{6}$ Among them, more than half underwent wisdom teeth removal after a complaint. Modern studies in this field pay considerable attention to impacted, semi-impacted, and embedded lower teeth. ${ }^{7-9}$ The lower jaw is exposed to speculation not by accident. Diseases associated with third molars or problems with their eruption

(c) 2020. European Journal of Dentistry.

This is an open access article published by Thieme under the terms of the Creative Commons Attribution-NonDerivative-NonCommercial-License, permitting copying and reproduction so long as the original work is given appropriate credit. Contents may not be used for commercial purposes, or adapted, remixed, transformed or built upon. (https://creativecommons.org/licenses/by-nc-nd/4.0/)

Thieme Medical and Scientific Publishers Pvt. Ltd., A-12, 2nd Floor, Sector 2, Noida-201301 UP, India 
are found, according to various sources, two to eight times more often in the lower jaw than in the upper jaw. ${ }^{10}$

The common treatment practice is to remove third molars before the tooth roots form, that is, above the age of 10 . The rate of postoperative recovery is more rapid in young patients compared with the older population. Hence, it is recommended to remove third molars to prevent tooth displacement and impaction cases from developing. ${ }^{11} \mathrm{At}$ the same time, opinions regarding the role of wisdom teeth in the development of overcrowding divide; some authors view the eruption of third molars as a provocative factor, while others do not assign a significant role to the said process. $^{8,9,12}$

Study on Turkish orthopaedic patients revealed more than a half (54\%) of symptomatic third molars. No significant gender differences were observed. Of all impacted third molars, $61 \%$ were partially buried in the bone, while the remaining molars were completely buried. Patients were 20 to 39 years old when preventive removal is rather challenging. ${ }^{13}$ This work attempts to analyze third molars with respect to the face type (e.g., leptoprosopic, etc.). The results will permit the prediction of anomalies in the third molar eruption depending on the type of the patient's face.

The purpose of this study is to justify the possibility of utilizing morphometric methods to foresee problems in the eruption of third molars. The research objective is to conduct a morphometric study of the lower jaws in adults with intact dentition and diagnosed with an impacted third molar. It is a small retromolar space that is the cause of third molar eruption. The research hypothesis is that smaller retromolar space leads to the abnormal eruption of wisdom teeth.

\section{Materials and Methods}

\section{Materials}

The study, which was conducted in 2018/2019, involves 100 skulls of young people aged 20 to 35 years. The skulls used here belong to Homo sapiens (53 males and 47 females). All Homo sapiens skulls were Caucasian. The mean age in the group is $26.0 \pm 4.0$ years (males, $28.0 \pm 2.0$; females, $24.0 \pm 2.0$ ).

Data on the said skulls were taken from the collection database of antropogenez.ru (anthropology website). Skulls belonging to other age groups were not studied, as the age range between 20 and 35 years is characterized by the complete formation of the skeleton, whereupon different parts, including the lower jaw, reach stabilization. For the subsequent analysis, the first group (Homo sapiens) was divided into two subgroups: (I) an intact dentition group (includes 60 skulls: 32 male and 28 female); and (II) a group with impacted third molars or an impaction group (includes 40 skulls: 21 male and 19 female). An even male/female distribution within groups allows a comparative study without gender bias. Inclusion criteria: healthy (intact) bite (intact dentition group); impacted third molars (impaction group). Each group was exposed to standard ${ }^{14}$ and nonstandard craniological analysis of the lower jaw and the face

\section{Methods for Studying Skull Morphology}

The craniological analysis includes traditional and nonstandard measurements specifically selected within the framework of the study.

\section{Traditional Craniological Measurements}

1. Gonial angle (M 79).

2. Bicondylar breadth: Straight distance between the most lateral points on the two condyles (M 65).

3. Bi-coronoid breadth: Distance between the apices of the two coronoid processes (M 65 [1]).

4. Bi-gonial width: Distance between right and left gonion (M 66).

5. Mandibular length: Distance of anterior margin of the chin from a center point on a projected straight line placed along the posterior border of two mandibular angles (M 68).

6. Condyloid height: Distance between the most cranial point of the condyle and the gonion (M 70).

7. Retromolar width: Distance between the distal part of the second molar crown and the mental foramen. ${ }^{14}$

\section{Nonstandard Craniological Measurements}

1. Mandibular length in the angle area: Distance between the intersection point on the straight line that in the occlusal plane descends from the tip of the cusp on the second molar to the anterior border of the ramus and the point at the cervical third of the same molar, on the distal surface.

2. Mandibular thickness in the retromolar region.

3. Mandibular height in the retromolar region.

Within each group, two additional characteristics were taken into account, gender and facial index (the length of the face divided by the breadth multiplied by 100).

\section{Measurements for Third Molars that Were Removed}

1. Mesiodistal crown dimensions.

2. Vestibule-oral crown dimensions.

All measurements were taken by a single researcher in triplicate and then processed with Past v. 3.0. The means and standard deviations were calculated. The differences between variables were significant at $p \leq 0.05$. To identify significant differences, an independent sample $t$-test was addressed.

\section{Results}

Differences were established between variables in the impaction group and variables in the intact dentition group, whereas lower values were found among the group of skulls with impacted third molars (-Table 1).

Differences in variables that are linked to the retromolar region and the mandibular length in the angle area are proven reliable. Morphological variables such as face width and face height significantly differ in men. Hence, gender is important when studying face morphology. The maximum face height was found in leptoprosopic skulls, while the minimum values were characteristic of euryprosopic skulls. The 
Table 1 Morphometric and craniological characteristics of facial skeleton and lower jaw in intact dentition and impaction skull subgroups (Homo sapiens, $n=100$ skulls)

\begin{tabular}{|c|c|c|c|c|c|c|}
\hline \multirow[t]{2}{*}{ Variable } & \multirow[t]{2}{*}{ Skull group } & \multicolumn{5}{|c|}{ Value, mean \pm standard deviation } \\
\hline & & Male & Female & Long face & Round face & Broad face \\
\hline \multirow{2}{*}{$\begin{array}{l}\text { Face width } \\
\text { (bizygomatic) }\end{array}$} & Intact dentition & $132.0 \pm 1.4$ & $124.5 \pm 1.9^{b}$ & $124.6 \pm 1.3$ & $128.9 \pm 1.8^{c}$ & $134.5 \pm 2.4^{c}$ \\
\hline & Impaction & $129.9 \pm 1.5$ & $123.0 \pm 1.0^{\mathrm{b}}$ & $122.4 \pm 2.1$ & $126.9 \pm 1.6^{c}$ & $132.3 \pm 2.7^{c}$ \\
\hline \multirow[t]{2}{*}{ Face height } & Intact dentition & $70.1 \pm 1.0$ & $66.9 \pm 1.0^{\mathrm{b}}$ & $71.7 \pm 0.9$ & $67.9 \pm 1.0^{c}$ & $65.3 \pm 1.5^{c}$ \\
\hline & Impaction & $66.0 \pm 0.9$ & $64.4 \pm 0.8^{b}$ & $69.4 \pm 0.8$ & $66.3 \pm 1.0^{c}$ & $64.1 \pm 0.9^{c}$ \\
\hline \multirow[t]{2}{*}{ Gonial angle } & Intact dentition & $122.9 \pm 1.3$ & $126.7 \pm 1.9^{b}$ & $125.7 \pm 1.2$ & $125.0 \pm 1.8^{c}$ & $120.1 \pm 2.5^{c}$ \\
\hline & Impaction & $122.4 \pm 1.3$ & $126.5 \pm 1.8^{\mathrm{b}}$ & $123.2 \pm 1.1$ & $122.0 \pm 1.4^{c}$ & $118.1 \pm 1.2^{c}$ \\
\hline \multirow[t]{2}{*}{ Bicondylar breadth } & Intact dentition & $116.9 \pm 1.3$ & $113.3 \pm 2.1^{\mathrm{b}}$ & $113.4 \pm 1.9$ & $114.9 \pm 1.3$ & $117.3 \pm 2.0$ \\
\hline & Impaction & $114.0 \pm 1.5$ & $111.8 \pm 1.4^{\mathrm{b}}$ & $112.8 \pm 2.1$ & $113.3 \pm 3.8$ & $115.0 \pm 1.3$ \\
\hline \multirow[t]{2}{*}{ Bi-coronoid breadth } & Intact dentition & $95.4 \pm 1.2$ & $89.7 \pm 1.0^{\mathrm{b}}$ & $92.1 \pm 1.3$ & $92.4 \pm 1.3$ & $96.9 \pm 2.6$ \\
\hline & Impaction & $93.2 \pm 0.9$ & $87.2 \pm 0.9^{b}$ & $91.8 \pm 1.2$ & $91.9 \pm 1.3$ & $95.4 \pm 1.4$ \\
\hline \multirow[t]{2}{*}{ Bi-gonial width } & Intact dentition & $100.8 \pm 1.3$ & $95.2 \pm 2.6^{\mathrm{b}}$ & $95.8 \pm 1.6$ & $98.3 \pm 1.6$ & $101.8 \pm 2.9$ \\
\hline & Impaction & $96.9 \pm 1.6$ & $93.4 \pm 1.4^{\mathrm{b}}$ & $93.8 \pm 2.3$ & $96.5 \pm 1.5$ & $98.7 \pm 2.4$ \\
\hline \multirow[t]{2}{*}{ Mandibular length } & Intact dentition & $78.5 \pm 0.9$ & $73.1 \pm 1.5^{\mathrm{b}}$ & $74.9 \pm 1.6$ & $75.3 \pm 0.9^{c}$ & $80.3 \pm 1.4^{c}$ \\
\hline & Impaction & $76.6 \pm 1.2$ & $71.3 \pm 1.8^{\mathrm{b}}$ & $74.0 \pm 1.7$ & $75.1 \pm 1.7^{c}$ & $77.0 \pm 2.5^{c}$ \\
\hline \multirow[t]{2}{*}{ Condyloid height } & Intact dentition & $62.8 \pm 1.1$ & $56.9 \pm 0.9^{b}$ & $59.7 \pm 1.1$ & $59.6 \pm 1.3$ & $62.5 \pm 2.6$ \\
\hline & Impaction & $60.1 \pm 1.0$ & $55.4 \pm 0.8^{b}$ & $58.8 \pm 1.0$ & $59.0 \pm 1.1$ & $61.3 \pm 1.8$ \\
\hline \multirow[t]{2}{*}{ Retromolar width } & Intact dentition & $32.3 \pm 1.4$ & $29.5 \pm 1.0^{\mathrm{b}}$ & $32.3 \pm 1.2$ & $29.9 \pm 1.5$ & $29.0 \pm 1.0$ \\
\hline & Impaction & $27.4 \pm 1.8^{\mathrm{a}}$ & $26.3 \pm 1.7^{\mathrm{a}, \mathrm{b}}$ & $26.2 \pm 1.3^{\mathrm{a}}$ & $24.8 \pm 1.3^{\mathrm{a}}$ & $23.1 \pm 1.1^{\mathrm{a}}$ \\
\hline \multirow{2}{*}{$\begin{array}{l}\text { Mandibular length in } \\
\text { the angle area }\end{array}$} & Intact dentition & $24.1 \pm 1.4$ & $22.3 \pm 0.8$ & $25.1 \pm 0.9$ & $22.0 \pm 1.2^{c}$ & $20.0 \pm 2.1^{c}$ \\
\hline & Impaction & $20.7 \pm 0.6^{a}$ & $20.4 \pm 1.0^{\mathrm{a}}$ & $20.4 \pm 0.9^{a}$ & $18.9 \pm 0.8^{\mathrm{a}, \mathrm{c}}$ & $17.6 \pm 1.1^{\mathrm{a}, \mathrm{c}}$ \\
\hline \multirow{2}{*}{$\begin{array}{l}\text { Mandibular thickness } \\
\text { in the retromolar } \\
\text { region }\end{array}$} & Intact dentition & $16.1 \pm 0.6$ & $14.9 \pm 0.6$ & $15.2 \pm 0.6$ & $15.4 \pm 0.7$ & $17.0 \pm 1.0$ \\
\hline & Impaction & $15.2 \pm 0.6^{\mathrm{a}}$ & $13.9 \pm 0.6^{a}$ & $14.7 \pm 0.7^{a}$ & $14.9 \pm 0.6^{a}$ & $16.0 \pm 1.2^{\mathrm{a}}$ \\
\hline \multirow{2}{*}{$\begin{array}{l}\text { Mandibular height } \\
\text { in the retromolar } \\
\text { region }\end{array}$} & Intact dentition & $42.3 \pm 0.8$ & $40.1 \pm 0.9$ & $41.5 \pm 0.7$ & $41.4 \pm 0.9$ & $38.5 \pm 5.5$ \\
\hline & Impaction & $39.5 \pm 1.3^{\mathrm{a}}$ & $37.7 \pm 1.5^{a}$ & $38.6 \pm 1.7^{\mathrm{a}}$ & $38.1 \pm 1.2^{\mathrm{a}}$ & $36.3 \pm 2.0^{\mathrm{a}}$ \\
\hline
\end{tabular}

adifferences are statistically significant between group 1 and group $2(p \leq 0.05)$.

${ }^{b}$ women demonstrate differences at a statistically significantly higher level than men.

cdifferences are statistically significant compared with long faces.

mesoprosopic skulls have the average values of face height. According to the FI data gathered for subgroup I, leptoprosopic skulls dominate with the $41 \%$ proportion, followed by mesoprosopic skulls (37\%), and euryprosopic skulls (22\%). In the subgroup II, the proportion of leptoprosopic skulls is reaching $51 \%$, while the proportion of mesoprosopic skulls remains almost the same, $34 \%$. The percentage of skulls with broad faces is the lowest, $15 \%$.

For leptoprosopic skulls, differences in the gonial angle and in the angle section length $(p \leq 0.05)$ are also significant. In the euriprosopic skulls, values of the face width and the mandibular length are also significantly different from other skull groups ( $p \leq 0.05)$.

Between the male and female skulls, significant differences were found in the following variables $(p \leq 0.05)$ : the face width, face height, gonial angle, bicondylar breadth, bi-coronoid breadth, mandibular length, ramus height, and the retromolar width. These findings indicate significant gender-based differences in the structure of the facial skeleton.
Significant differences were also obtained for the third molar crown dimensions ( $p \leq 0.001$ ); men have third molar crowns 1.25 times larger in mesiodistal size (-Fig. 1) and 1.23 times larger in vestibulo-oral size.

The retromolar width is nothing more than the sum of distances, one from the distal part of the second molar crown to the anterior border of the ramus, and another from the anterior border to a mandibular foramen of the ramus mandibulae. The position of the foramen is gender independent. On average, the retromolar width is $18 \mathrm{~mm}$ in an adult. According to the present data, the retromolar width in the impaction group is approximately $27.5 \mathrm{~mm}$ in men and $26.2 \mathrm{~mm}$ in women. By subtracting $18 \mathrm{~mm}$ from these numbers, one will obtain the space necessary for the normal eruption of the third molar. In the impaction group, the length of this space is meant to be $9.5 \mathrm{~mm}$ in men and $8.4 \mathrm{~mm}$ in women, which does not comply with the mesiodistal size of the third molar given in - Fig. 1 .

As it follows from findings provided earlier, if the distance from the distal part of the second molar crown to the anterior 


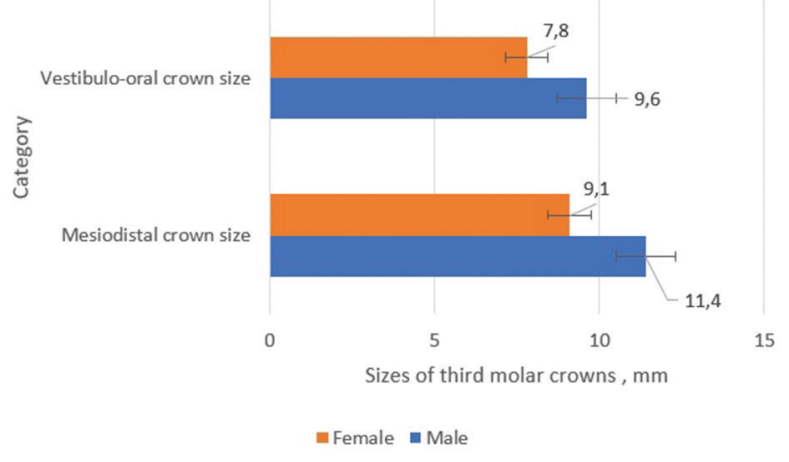

Fig. 1 Sizes of third molar crowns in males and females.

border of the ramus does not exceed $9.5 \mathrm{~mm}$, then the impaction will not occur. This phenomenon was found in one-third of female skulls and in two-thirds of male skulls. Therefore, the impaction of the lower third molars is less of the characteristic of women than of men. Among all the skulls that were examined, male skulls with impacted third molars accounted for $60 \%$, while the female skulls made up only $40 \%$.

\section{Discussion}

Failure in the eruption of the third molar causes the appearance of embedded teeth. This displacement is the most common anomaly among others, one that accounts for almost three quarters of examined patients. Impaction and semi-impaction account for the remaining quarter. ${ }^{15-17}$

Dental procedures for tooth treatment or removal require a lot of time, which may cause some inconvenience to both doctors and patients. ${ }^{18}$ The tooth autotransplantation, for instance, may be complicated by root resorption. Nevertheless, these challenges do not affect the long-term overall outcome of prosthetics. ${ }^{19}$ From this it follows that third molars need to be extracted earlier in people having a certain type of face. This work shows the relationship between face type and detected abnormalities. The abnormal eruption of the third molar may result in malocclusion and consequently in facial soft tissue imbalance. ${ }^{20}$

There is not enough room for all of the teeth in the lower jaw and the retromolar space is not big enough in size for the third molar to erupt normally. This may cause lower teeth to crowd, especially when there are additional teeth such as premolars and distomolars that are symptomatic. This was the case detected in Spain, where the majority of supernumerary teeth (78\%) were impacted. ${ }^{21}$

In people living during the Neolithic and Paleolithic era, the distance from the middle of the articular head to the central incisors was ranging from 110 to $124 \mathrm{~mm}$ (Heidelberg jaw). Today, it does not exceed $100 \mathrm{~mm}$. The challenging and late eruption of the wisdom tooth is conditioned by the anatomy of the lower jaw. For instance, little room for the third molar has resulted from the evolution of the masticatory apparatus. At present, back teeth have almost completely lost their function due to the change of diet.. ${ }^{22}$ So far, the reduction of the third molar causes the failure of eruption in many people. Therefore, studies on the possibility of predicting the abnormal eruption of the third molar continue to be relevant.

The frequency of various face types varies between ethnic groups. The face type defines the width of the mandible. For instance, individuals with a brachyfacial face have a significantly thicker mandibular shape as compared with individuals having a mesofacial type of face. At the same time, brachyfacial individuals have smaller mandibular inclination. ${ }^{23}$ In this work, facial patterns were also examined, and a connection between facial patterns and the number of anomalies in the third molar was found.

\section{Conclusions}

This work allows detecting abnormalities in the eruption of the third molar with high probability of success. The abnormalities in point are considered not only those associated with the generally accepted parameters but also those that occur in the leptoprosopic face cases. Face type and the structural features of the facial skeleton play a significant role in the abnormal eruption of the lower third molar.

\section{Data Availability}

Data will be available on request.

\section{Funding}

None.

\section{Conflict of Interest}

None declared.

\section{Acknowledgments}

The author wishes to express gratitude for access to the craniological collection to Giacomo Palatucci, Medicine Academy of Turin, Italy. The author wishes to express his gratitude for access to the craniological collection to Alexander Sokolov, the owner of the anthropology-related website http://antropogenez.ru/contacts/.

\section{References}

1 Allen RT, Witherow H, Collyer J, Roper-Hall R, Nazir MA, Mathew G. The mesioangular third molar-to extract or not to extract? Analysis of 776 consecutive third molars. Br Dent J 2009;206(11):E23, discussion 586-587

2 Chang SW, Shin SY, Kum KY, Hong J. Correlation study between distal caries in the mandibular second molar and the eruption status of the mandibular third molar in the Korean population. Oral Surg Oral Med Oral Pathol Oral Radiol Endod 2009;108(6):838-843

3 McArdle LW, Renton TF. Distal cervical caries in the mandibular second molar: An indication for the prophylactic removal of the third molar? Br J Oral Maxillofac Surg 2006;44(1):42-45

4 Worrall SF, Riden K, Haskell R, Corrigan AM. UK National Third Molar project: the initial report. Br J Oral Maxillofac Surg 1998;36(1):14-18

5 Ozeç I, Hergüner Siso S, Taşdemir U, Ezirganli S, Göktolga G. Prevalence and factors affecting the formation of second molar distal caries in a Turkish population. Int J Oral Maxillofac Surg 2009;38(12):1279-1282 
6 Falci SG, de Castro CR, Santos RC, et al. Association between the presence of a partially erupted mandibular third molar and the existence of caries in the distal of the second molars. Int J Oral Maxillofac Surg 2012;41(10):1270-1274

7 Oderinu OH, Adeyemo WL, Adeyemi MO, Nwathor O, Adeyemi MF. Distal cervical caries in second molars associated with impacted mandibular third molars: A case-control study. Oral Surg Oral Med Oral Pathol Oral Radiol 2012; (e-pub ahead of print). doi: 10.1016/j.00oo.2012.03.039

8 McArdle LW, McDonald F, Jones J. Distal cervical caries in the mandibular second molar: an indication for the prophylactic removal of third molar teeth? Update. Br J Oral Maxillofac Surg 2014;52(2):185-189

9 Toedtling V, Coulthard P, Thackray G. Distal caries of the second molar in the presence of a mandibular third molar-a prevention protocol. Br Dent J 2016;221(6):297-302

10 Blakey GH, Marciani RD, Haug RH, et al. Periodontal pathology associated with asymptomatic third molars. J Oral Maxillofac Surg 2002;60(11):1227-1233

11 Office for National Statistics National Population Projections. 2014. Statistical Bulletin. 2015. Available at: https://www.ons. gov.uk/peoplepopulationandcommunity/populationandmigration/populationprojections/bulletins/nationalpopulationprojections/2015-10-29. Accessed May 13, 2020

12 McArdle LW, Andiappan M, Khan I, Jones J, McDonald F. Diseases associated with mandibular third molar teeth. $\mathrm{Br}$ Dent J 2018;224(6):434-440

13 Topkara A, Sari Z. Investigation of third molar impaction in Turkish orthodontic patients: prevalence, depth and angular positions. Eur J Dent 2013;7(1, Suppl 1) :S094-S098

14 Martin R, Lehrbuch der Anthropologie. 2nd ed. Jena: Fischer; 1928
15 Adeyemo WL, James O, Ogunlewe MO, Ladeinde AL, Taiwo OA, Olojede AC. Indications for extraction of third molars: a review of 1763 cases. Niger Postgrad Med J 2008;15(1):42-46

16 Pepper T, Grimshaw P, Konarzewski T, Combes J. Retrospective analysis of the prevalence and incidence of caries in the distal surface of mandibular second molars in British military personnel. Br J Oral Maxillofac Surg 2017;55(2):160-163

17 McArdle LW, Jones J, McDonald F. Characteristics of disease related to mesio-angular mandibular third molar teeth. $\mathrm{Br} \mathrm{J}$ Oral Maxillofac Surg 2019;57(4):306-311

18 Al-Khalifa KS, Baeshen HA. Micro-osteoperforations and its effect on the rate of tooth movement: a systematic review. Eur J Dent 2020; (e-pub ahead of print). Doi: 10.1055/s-0040-1713955

19 Lacerda-Santos R, Canutto RF, Araújo JLDS, et al. Effect of orthodontic treatment on tooth autotransplantation: systematic review of controlled clinical trials. Eur J Dent 2020. Doi: 10.1055/s-0040-1708329

20 Ardani IGAW, Dinata FC, Triwardhani A. The importance of the occlusal plane in predicting better facial soft tissue in class II malocclusion in ethnic Javanese. Eur J Dent 2020. Doi: 10.1055/s-0040-1713331

21 Brinkmann JC, Martínez-Rodríguez N, Martín-Ares M, et al. Epidemiological features and clinical repercussions of supernumerary teeth in a multicenter study: A review of 518 patients with hyperdontia in Spanish population. Eur J Dent 2020;14(3):415-422 doi:10.1055/s-0040-1712860

22 Bezrukov IM, Rabukhina NA, Deformation of the facial skull. Medical Information Agency LLC; Moscow, Russia: 2005

23 Ferreira MC, Freitas KMS, Herrera-Sanches FS, et al. Evaluation of mandibular first molars' axial inclination and alveolar morphology in different facial patterns: a CBCT study. Eur J Dent 2020;14(2):250-259 